\title{
Isolation of cDNAs for Genes Expressed after/during Fertilization and Fruit Set of Melon (Cucumis melo L.)
}

\author{
Masaki Nagasawa, Hitoshi Mori, Katsuhiro Shiratake and Shohei Yamaki* \\ Graduate School of Bioagricultural Sciences, Nagoya University, Nagoya 464-8601
}

\begin{abstract}
Summary
Fertilization is an important event leading to fruit set. Tips of pollen tubes reached the ovules at the base of the ovary within $24 \mathrm{hr}$ after pollination. Therefore, cDNAs for genes preferentially expressed after/during fertilization were isolated by suppression subtractive hybridization between cDNAs from pollinated and unpollinated fruits. Using cDNA macroarrays, 384 cDNA clones of the subtracted cDNA library were differentially screened by the probes of the cDNAs from pollinated or unpollinated fruit 1 day after anthesis. By Northern blot analyses, mRNAs, corresponding to 14 cDNA clones, were more concentrated in pollinated fruit than in the unpollinated ones. The deduced amino acid sequence of genes corresponding to these cDNA clones showed a similarity with ascorbate oxidase, hydroxymethyltransferase, phosphoethanolamine $N$-methyltransferase, short chain alcohol dehydrogenase, histone H2A, auxin binding protein, 14-3-3 protein, extensin-like protein, nucleoid DNA-binding-like protein, type IIIa membrane protein (reversibly glycosylated polypeptide), and hypothetical proteins. In melon, $N$ - (2-chloro-4-pyridyl)- $N^{\prime}$ - phenylurea (CPPU) induced parthenocarpy without pollination, whereas 4-chlorophenoxyacetic acid (4-CPA) was less effective on producing parthenocarpic fruit. mRNAs corresponding to $14 \mathrm{cDNA}$ clones were expressed in both pollinated and CPPU - treated fruit. Expressions of mRNAs corresponding to all cDNA clones in pollinated and CPPU - treated fruit were higher than those in 4-CPA-treated fruit. These mRNAs were barely detectable in the later stages of fruit development and were expressed preferentially in fruit except for $6 E 04$ and $6 H 01$. Especially, expression patterns of $8 A 07$ (nucleoid DNA-binding-like protein) and $8 D 10$ (short chain alcohol dehydrogenase) lead us to speculate that they play important roles in fruit set because they are expressed at a higher level in the early stages of both pollinated and CPPU - treated fruit than that of $4-\mathrm{CPA}$ - treated fruit.
\end{abstract}

Key Words: $N$-(2-chloro-4-pyridyl)- $N$ '-phenylurea (CPPU), fertilization, fruit set, pollination, suppression subtractive hybridization.

\section{Introduction}

Fertilization is generally a prerequisite to fruit set. It is considered that fruit set depends on the successful completion of pollination and fertilization in normal fruit development. The presence of fertilized ovules generally triggers the continuous development of an ovary into a fruit (Gillaspy et al., 1993). Pollination and fertilization provide growth stimuli or signal(s) for fruit setting by promoting synthesis of plant hormones, such as auxins, gibberellins and cytokinins. For example, indole-3-acetic acid (IAA) content of mesocarp increases in pollinated fruit 1 day after anthesis in melon 'Prince' (Lee et al., 1997).

In some plants, fruit set is induced in the absence of

Received; December 26, 2003. Accepted; May 6, 2004.

Part of this work was supported by a grants-in-aid (No. 13460013) from the Ministry of Education, Culture, Sports, Science and Technology of Japan.

Parts of this article were presented at the year 2003 Fall Meeting of the Japanese Society for Horticultural Science.

* Corresponding author (E-mail: yamaki@agr.nagoya-u.ac.jp). pollination and fertilization, a phenomenon known as parthenocarpy. Exogenously applied CPPU, a synthetic cytokinin, induces parthenocarpy in muskmelon (Hayata et al., 2000) and watermelon (Hayata et al., 1995). Several genes, involved in natural parthenocarpic fruit development in tomato (Lycopersicon esculentum), were described (Barg et al., 1990; Fos and Nuez, 1996, 1997; Testa et al., 2002). Transgenic eggplants and tomatoes, expressing the coding region of the iaaM gene in the ovule, promote parthenocarpic fruit development (Ficcadenti et al., 1999; Rotino et al., 1997). Parthenocarpic fruit was produced by transposon insertion mutations in a MADS-box transcription factor in apple (Malus domestica) (Yao et al., 2001). Recently, Carmi et al. (2003) reported that ovary-specific expression of the rolB gene induced parthenocarpy in tomato.

cDNAs for genes that are preferentially expressed in pollinated fruit 3 days after anthesis in cucumber (Cucumis sativum) (Suyama et al., 1999) and those in pollinated fruit 3 days after anthesis (Nagasawa et al., 2001) and 2 days after anthesis (Nagasawa et al., 2004) in eggplant, were isolated by subtractive hybridization. 
cDNAs for genes, preferentially expressed in early fruit development, were isolated by differential display in tomato (Lemaire-Chamley et al., 2000; Tieman and Handa, 1996) and pollinated strawberry (Fragaria $\times$ ananassa) (Hamano et al., 1998), and by differential screening in auxin-treated strawberry (Reddy et al., 1990), peach (Prunus persica) (Callahan et al., 1993), kiwifruit (Actinidia deliciosa) (Ledger and Gardner, 1994), and apple (Dong et al., 1997, 1998). Interestingly, similar cDNA clones were isolated from several species; e.g. ribosomal protein, histone $\mathrm{H} 2 \mathrm{~A}$, polyphenol oxidase, and cytochrome P450. However, the molecular signal (s) for fruit set and early fruit development are not clear.

A number of studies have been reported on the isolation of cDNAs for genes that are preferentially expressed during early fruit development, but they have not targeted the stage of fertilization except for our recent report (Nagasawa et al., 2004). In that report, we isolated cDNAs for genes preferentially expressed after/during fertilization (i.e., in pollinated fruit 2 days after anthesis) in eggplant (Nagasawa et al., 2004). Since fertilization is an important step for fruit set, cDNAs for genes that are preferentially expressed after/during fertilization are assumed to play important roles in the process. In this study, we aimed to isolate cDNAs for genes after/during fertilization in melon. Further, CPPU induces parthenocarpy without pollination in melon (Hayata et al., 2000), whereas 4-CPA that induces parthenocarpy in eggplant is less effective on parthenocarpy in melon. Therefore, we analyzed the expression of genes in pollinated, CPPU-treated-, and 4-CPA-treated melon fruit.

\section{Materials and Methods}

\section{Plant material}

Anthers on melon (Cucumis melo L.) 'Prince' (Sakata Seed Co., Yokohama) seedlings growing in the field of Nagoya University, were removed 1 day before anthesis; the flowers were covered with paper bags to prevent natural pollination. Flowers were treated as follows: 1) hand-pollinated at anthesis (pollinated fruit); 2) sprayed unpollinated ovaries with 100 ppm CPPU containing $0.1 \%(\mathrm{w} / \mathrm{v}$ ) Tween 20 (CPPU-treated fruit); 3) sprayed ovaries of unpollinated flowerws with $50 \mathrm{ppm} \mathrm{4-CPA}$ mixed with $0.1 \%(\mathrm{w} / \mathrm{v})$ Tween 20 (4-CPA-treated fruit); and 4) emasculated unpollinated flowers as a control (unpollinated fruit). After treatments, all flowers were covered with paper bags again. Fruits were sampled periodically, frozen immediately in liquid nitrogen, and stored at $-80^{\circ} \mathrm{C}$ until analyzed.

\section{Observation of pollen tube growth}

Pollinated flowers, harvested at 12 and $24 \mathrm{hr}$ after pollination in August 2000, were dissected, fixed, softened, and stained as described in previous paper
(Nagasawa et al., 2004). At least three flowers of each treatment were observed under a fluorescence microscope IX70 (Olympus, Co., Ltd. Tokyo) fitted with a combined filter (Olympus BP330-385, BA420, DM400).

\section{Isolation of poly $(A)^{+} R N A$}

Total RNA was extracted from $2 \mathrm{~g}$ of ovaries/fruits from which poly (A) ${ }^{+}$RNA was isolated as described by Suyama et al. (1999).

\section{Construction of the subtracted cDNA library}

The PCR-Select cDNA Subtraction Kit (Clontech, Palo Alto, CA) was used to make a cDNA library enriched for transcripts differentially abundant in pollinated fruit 1 day after anthesis. This protocol uses suppression PCR to enrich transcripts that are differentially expressed in the tester material (Diatchenko et al., 1996). The cDNA from pollinated fruit 1 day after anthesis was used as the tester, and the cDNA from unpollinated fruit 1 day after anthesis was used as the driver. Following PCR amplification, subtracted cDNAs were cloned into pT7Blue T-Vector (Novagen, Madison, WI) by using DNA Ligation Kit Ver. 2 (Takara Bio, Shiga).

\section{Sequence of CDNA and analysis}

Nucleotide sequences were determined by using a CEQ 2000 DNA sequencer (Beckman Coulter, Fullerton, CA) and CEQ Dye Terminator Cycle Sequencing Quick Start Kit (Beckman Coulter), or cDNA clones were sent to Dragon Genomics (Mie) for sequencing. Sequences were analyzed by using BLASTX against GenBank/EMBL/DDBJ non-redundant sequence databases.

\section{Differential screening using cDNA macroarrays}

Three hundred eighty-four cDNA clones were picked up randomly from the subtracted cDNA library; inserts were amplified by PCR $\left(94^{\circ} \mathrm{C}\right.$ for $30 \mathrm{sec}, 55^{\circ} \mathrm{C}$ for $30 \mathrm{sec}$, $72^{\circ} \mathrm{C}$ for $1 \mathrm{~min}$ for 35 cycles) using the primers 1 and $2 \mathrm{R}$ (Clontech). To prepare membranes for cDNA macroarray, PCR products were denatured with $0.5 \mathrm{~N} \mathrm{NaOH}$ and spotted onto Hybond-N+ membrane (Amersham Biosciences, Piscataway, NJ) by using Multimicro filter DP- 96 (Advantec, Tokyo). The first strand cDNA was synthesized from poly $(\mathrm{A}){ }^{+}$RNA isolated from a fruit. ${ }^{33} \mathrm{P}$ - labeled cDNA probe was synthesized from the first strand cDNA (300 ng) as a template. The membrane was hybridized with the ${ }^{33} \mathrm{P}$-labeled cDNA probes (equal specific activities among probes); hybridization was carried out as described by Suyama et al. (1999).

\section{Northern blot analysis}

Total RNA $(10 \mu \mathrm{g})$ was subjected to electrophoresis on $1.0 \%(\mathrm{w} / \mathrm{v})$ agarose gels and transferred to Hybond$\mathrm{N}+$ membrane. The membrane was hybridized with ${ }^{32} \mathrm{P}-$ 
labeled cDNA probes as above.

\section{Results}

\section{Growth of pollen tubes}

Tips of pollen tubes reached near the center of the ovary $12 \mathrm{hr}$ after pollination (Fig. 1A). Almost all tips entered the ovules at the base of the ovary within $24 \mathrm{hr}$ after pollination (Fig. 1B).
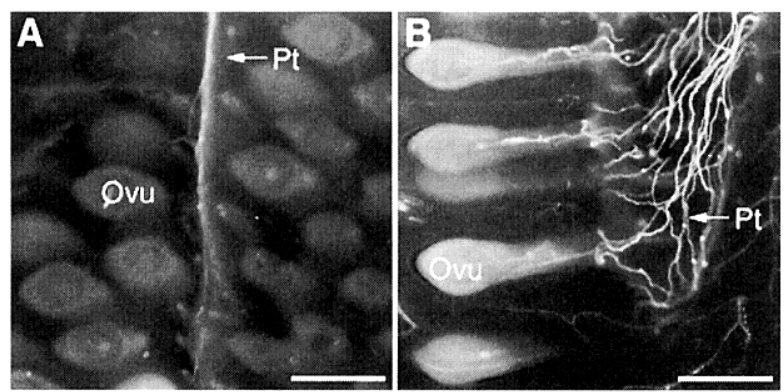

Fig. 1. Photomicrographs of pollen tube in melon ovaries. A: The center of an ovary $12 \mathrm{hr}$ after pollination, B: The basal side of ovary $24 \mathrm{hr}$ after pollination. Ovu, ovule; Pt, pollen tubes. Bars $=500 \mu \mathrm{m}$.

Table 1. Fruit set (\%) by hand-pollination, CPPU or 4 CPA treatment in melon.

\begin{tabular}{cc}
\hline \hline Treatment & Fruit set $(\%)$ \\
\hline Pollinated & $100(25 / 25)^{2}$ \\
CPPU & $100(11 / 11)$ \\
4-CPA & $8(1 / 12)$ \\
Unpollinated (Control) & $0(0 / 15)$ \\
\hline
\end{tabular}

Emasculated flowers were treated at anthesis and fruit set was determined 7 days later.

${ }^{2}$ Values in parentheses represent fruit set/treated flowers.

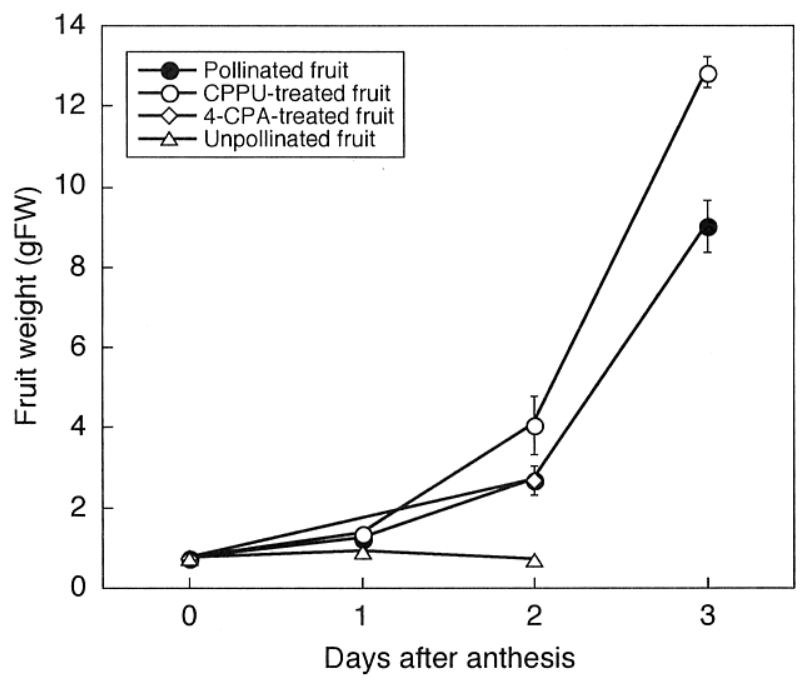

Fig. 2. Changes in fruit weight of melon during early fruit development. Values are means of five samples \pm SE.

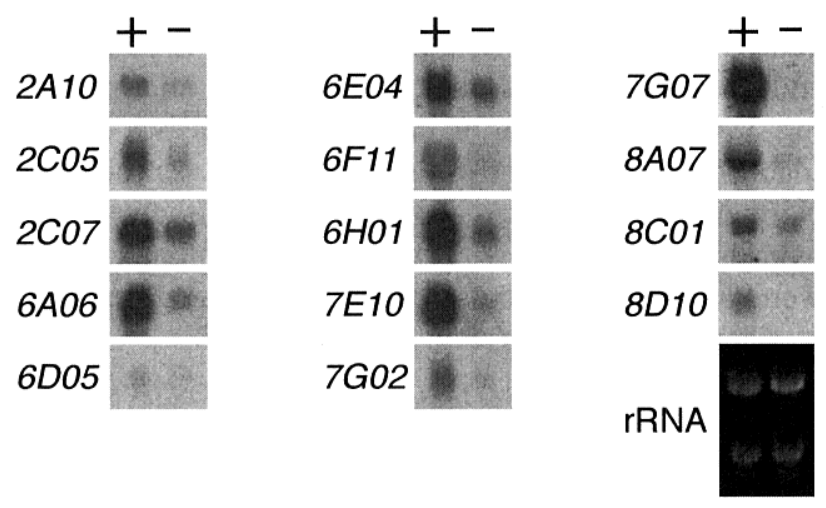

Fig. 3. Northern blot analyses of positive cDNA clones in pollinated fruit $(+)$ and unpollinated ones (-) 1 day after anthesis. Each lane represents $10 \mu \mathrm{g}$ of total RNA extracted from each sample.

Table 2. Characterization of cDNA clones for genes that were preferentially expressed after/during fertilization in melon.

\begin{tabular}{|c|c|c|c|c|c|}
\hline $\begin{array}{l}\text { cDNA } \\
\text { clone }\end{array}$ & $\begin{array}{c}\text { Accession } \\
\text { no. }\end{array}$ & Best database match & Source & $\begin{array}{c}\text { Accession } \\
\text { no. }\end{array}$ & $E$ value \\
\hline $2 \mathrm{~A} 10$ & AB154522 & Hypothetical protein & Arabidopsis thaliana & $\mathrm{AC} 007213$ & $2 \mathrm{e}^{-50}$ \\
\hline $2 \mathrm{C} 05$ & AB154523 & Hypothetical protein & A. thaliana & AB022218 & $2 \mathrm{e}^{-08}$ \\
\hline $2 \mathrm{C} 07$ & AB154524 & Ascorbate oxidase & Cucumis melo & AF233593 & $1 e^{-91}$ \\
\hline $6 \mathrm{~A} 06$ & $\mathrm{AB} 154525$ & Histone $\mathrm{H} 2 \mathrm{~A}$ & Oryza sativa & AP003144 & $1 \mathrm{e}^{-34}$ \\
\hline $6 \mathrm{D} 05$ & AB154526 & Auxin binding protein & Malus domestica & U77952 & $2 e^{-40}$ \\
\hline $6 \mathrm{E} 04$ & AB154527 & $14-3-3$ protein & Vigna angularis & АВ042299 & $e^{-114}$ \\
\hline $6 \mathrm{~F} 11$ & AB154528 & Hydroxymethyltransferase & A. thaliana & AY086929 & $e^{-136}$ \\
\hline $6 \mathrm{H} 01$ & AB154529 & Extensin-like protein & C. sativus & AF104392 & $2 \mathrm{e}^{-26}$ \\
\hline 7E10 & AB154530 & Hypothetical protein & A. thaliana & AB012244 & $1 \mathrm{e}^{-32}$ \\
\hline $7 \mathrm{G} 02$ & AB154531 & No hit & - & - & - \\
\hline $7 \mathrm{G} 07$ & AB154532 & Phosphoethanolamine $N$-methyltransferase & Spinacia oleracea & AF237633 & $5 e^{-93}$ \\
\hline $8 \mathrm{~A} 07$ & AB154533 & Nucleoid DNA-binding-like protein & O. sativa & AP003833 & $6 \mathrm{e}^{-08}$ \\
\hline \multirow[t]{2}{*}{$8 \mathrm{C} 01$} & AB154534 & Type IIIa membrane protein & V. unguiculata & $\mathrm{AF} 005279$ & $3 \mathrm{e}^{-74}$ \\
\hline & & Reversibly glycosylated polypeptide & Gossypium hirsutum & AJ292078 & $3 e^{-74}$ \\
\hline $8 \mathrm{D} 10$ & AB154535 & Short chain alcohol dehydrogenase & V. unguiculata & D88121 & $7 e^{-53}$ \\
\hline
\end{tabular}




\section{Fruit set of melon}

Pollinated fruit developed rapidly 3 days after anthesis, whereas unpollinated fruit did not develope and aborted within a week. Exogenously applied CPPU, a synthetic cytokinin, induced the growth of ovaries without pollination. An application of 4-CPA, a synthetic auxin, to the ovaries without pollination had little effect on parthenocarpy (Fig. 2, Table 1). A $100 \%$ fruit set was obtained with CPPU, which is equivalent to that obtained by hand-pollination (Table 1). Pollinated fruit produced seeds, but CPPU- and 4-CPA-treated fruit were seedless at maturity.

\section{Isolation of CDNA clones for genes expressed after/during fertilization in melon}

Using suppression subtractive hybridization, the subtracted cDNA library was constructed and differentially screened by the probes of the cDNAs from pollinated or unpollinated fruit 1 day after anthesis, using cDNA macroarray. Eighty candidates of cDNA clones for genes that were expressed at a higher level in pollinated fruit than unpollinated ones, were selected after screening 384 cDNA clones of the subtracted cDNA library (data not shown). Some of these were used as probes for Northern blot analyses. Fourteen clones showed that hybridization signals with mRNA from pollinated fruit were stronger than those from unpollinated fruit by Northern blot analyses (Fig. 3).

\section{Sequence analyses of isolated cDNAs}

Several cDNA clones corresponding to mRNAs, whose expression in pollinated fruit increased compared with the unpollinated one, exhibited a similarity to enzymes: 2C07 showed a similarity to ascorbate oxidase from melon (Accession no. AF233593); 6F11 had a similarity to hydroxymethyltransferase from Arabidopsis (AY086929); 7G07 showed a similarity to phosphoethanolamine $N$-methyltransferase from spinach (Spinacia oleracea) (AF237633); 8D10 showed a similarity to short chain alcohol dehydrogenase from cowpea (Vigna unguiculata) (D88121) and watermelon (Citrullus lanatus) (AB018559).

Likewise, the deduced amino acid sequence of 6A06 showed a similarity to histone $\mathrm{H} 2 \mathrm{~A}$ from rice (Oryza sativa) (AP003144). 6D05 had a similarity to auxin binding protein from apple (U77952). 6E04 showed a similarity to 14-3-3 protein from azuki bean (Vigna angularis) (AB042299). 6H01 had a similarity to extensin-like protein from cucumber (AF104392). The deduced amino acid sequence of $8 \mathrm{~A} 07$ had a similarity to nucleoid DNA-binding-like protein from rice (AP003833). 8C01 showed a similarity to both type IIIa membrane protein from cowpea (AF005279) and reversibly glycosylated polypeptide from cotton (Gossypium hirsutum)(AJ292078).

2A10, 2C05 and 7E10 showed a similarity to hypo- thetical proteins from Arabidopsis, AC007213, AB022218, and AB012244, respectively. 7G02 had no significant similar sequence in the database. The results of sequence analyses of isolated cDNA clones are in Table 2.

The nucleotide sequence data reported in this paper has been submitted to the DDBJ, EMBL and GenBank nucleotide sequence databases with the accession numbers AB154522 (2A10), AB154523 (2C05), AB154524 (2C07), AB154525 (6A06), AB154526 (6D05), AB154527 (6E04), AB154528 (6F11), AB154529 (6H01), AB154530 (7E10), AB154531 (7G02), AB154532 (7G07), AB154533 (8A07), AB154534

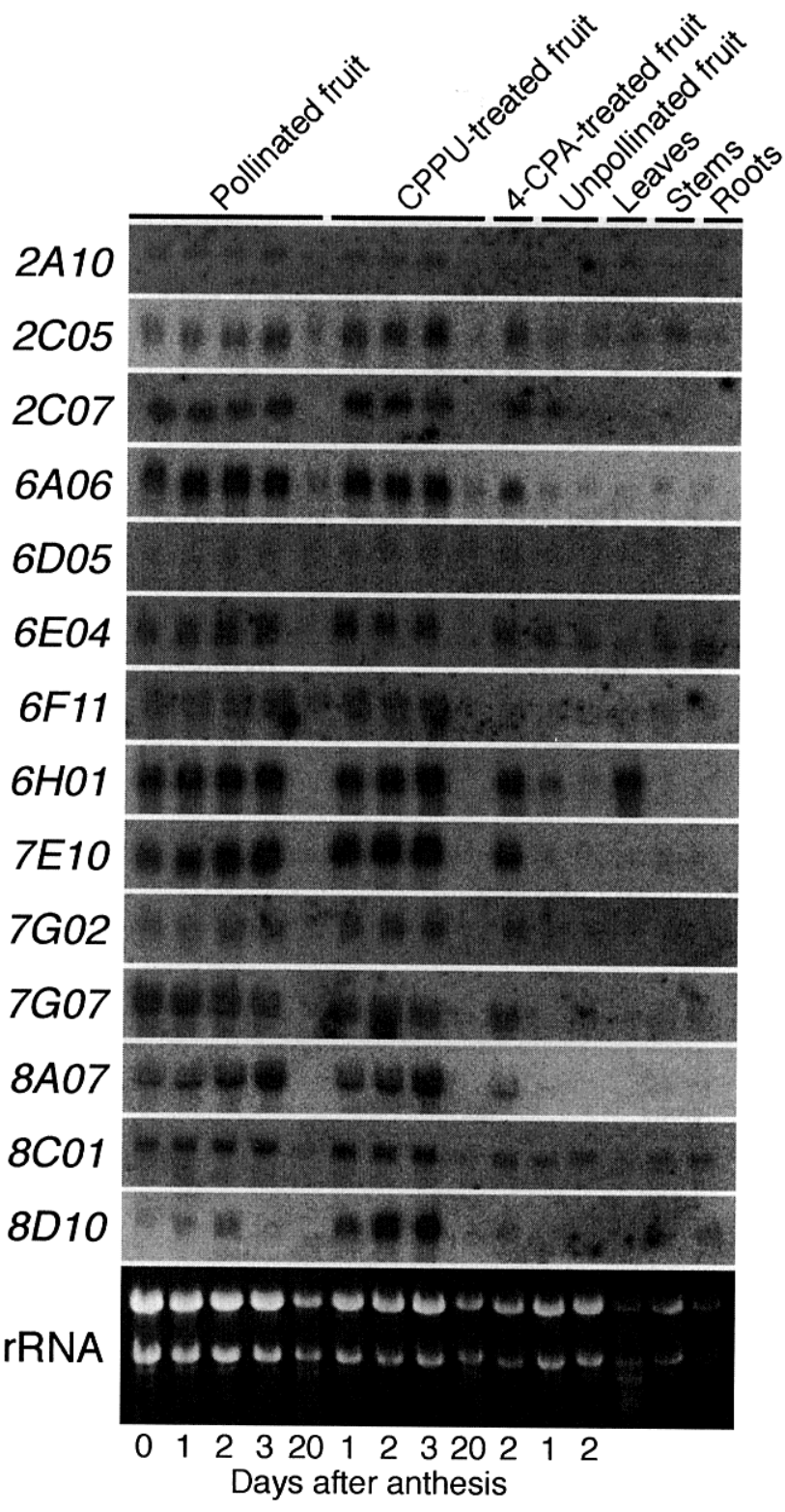

Fig. 4. Northern blot analyses showing temporal expression during fruit development and organ specific expression of mRNAs corresponding to isolated cDNA clones. Each lane represents $10 \mu \mathrm{g}$ of total RNA extracted from each sample. 
(8C01) and AB154535 (8D10).

\section{Temporal and organ specific expression of mRNAs corresponding to isolated cDNA clones}

Expressions of mRNAs corresponding to 14 cDNA clones were detected in the ovary at anthesis. 2C07, $6 F 11,7 G 07$ and $8 C 01$ mRNAs were expressed in steady - state levels in the early development of pollinated fruit, whereas expressions of mRNAs corresponding to the other 10 cDNA clones increased during early development of pollinated fruit. mRNAs corresponding to all 14 cDNA clones were also expressed in CPPU-treated fruit between 1 and 3 days after anthesis. Transcripts of these 14 cDNA clones were barely detectable 20 days after anthesis. The expressions of mRNAs corresponding to all cDNA clones in pollinated and CPPUtreated fruit were higher than those in 4-CPA-treated fruit. Expression pattern of only $8 D 10$ in pollinated fruit differed from that in CPPU-treated fruit. 6E04 mRNA was detected at a very low level in leaves, stems, and roots, whereas $6 \mathrm{HO1}$ mRNA was expressed at a high level in leaves (Fig. 4).

\section{Discussion}

Our photomicrographs (Fig. 1A, B) revealed that to isolate cDNAs for genes that signal fertilization, the ideal time to collect samples was 1 day after anthesis. In the melon 'Prince', pollination promoted the growth of ovaries, and CPPU, a synthetic cytokinin, had a similar effect on unpollinated ones (Fig. 2, Table 1). To understand the mechanism of fruit set, we compared the expression of mRNAs corresponding to isolated cDNAs among pollinated fruit, CPPU-treated fruit, 4-CPAtreated fruit and unpollinated fruit during the early stage of development (Fig. 4). mRNAs corresponding to isolated $14 \mathrm{cDNAs}$ were expressed in both pollinated and CPPU-treated fruit, which suggests that genes corresponding to these cDNAs are related to the pericarp development, but not seed formation. Furthermore, their expression patterns in pollinated fruits were similar to those in CPPU-treated fruits during fruit development except for $8 D 10$, which leads us to speculate that the mechanism of fruit set by CPPU is similar to that by pollination in many aspects.

Previously, we isolated cDNAs for genes preferentially expressed after/during fertilization (i.e. pollinated fruit 2 days after anthesis) in eggplant (Nagasawa et al., 2004). Their mRNAs corresponding to 3 cDNA clones were expressed at a higher level in pollinated and 4-CPA-treated fruit 2 to 4 days after anthesis than before pollination occurred. In this study, cDNAs for genes that were preferentially expressed after/during fertilization (i.e. pollinated fruit 1 day after anthesis) in melon were sought. Expressions of mRNAs corresponding to 10 of 14 cDNA clones increased after/during (i.e. between 1 to 3 days after anthesis) fertilization (Fig. 4) indicating that the mRNAs corre- sponding to these cDNA clones were expressed increasingly during early fruit development when fruit set was being initiated.

2C07 showed a similarity to ascorbate oxidase. Ascorbate oxidase mRNA was expressed at a high level in ovaries in muskmelon (Diallinas et al., 1997). Ascorbate oxidase is induced by auxin in pumpkin (Cucurbita spp.) (Esaka et al., 1992). IAA content in mesocarp of pollinated fruit during early development was higher than that in the later stage in the melon 'Prince' (Lee et al., 1997); that of CPPU-treated fruit increased from anthesis to 2 days later in muskmelon (Hayata et al., 2002). In addition, expression of $2 \mathrm{CO} 7$ was also induced by exogenous 4-CPA that had little effect on parthenocarpy. These results suggest that expression of $2 \mathrm{CO}$ may be induced by endogenous and/or exogenous auxin.

6F11 has a similarity to serine hydroxymethyltransferase, the enzyme that catalyzes the reversible conversion of serine and tetrahydrofolate to glycine and 5,10-methylene tetrahydrofolate (Schirch, 1982), which leads us to speculate that pollination initiates diverse metabolic activities in the early stage of fruit development.

$7 \mathrm{G} 07$ shows a similarity to phosphoethanolamine $N$ methyltransferase, a key enzyme in the synthesis of choline, which is responsible for membrane synthesis (Rhodes and Hanson, 1993). Phosphoethanolamine $N$ methyltransferase mRNA may be expressed during the early stage of fruit development to synthesize membranes.

8D10 shows a similarity to short chain alcohol dehydrogenase that is expressed in pollinated watermelon seeds but not in the fruit 2 days after pollination (Kim et al., 2003). However, our results showed that $8 D 10$ was expressed in both pollinated fruit and CPPU-treated seedless fruit in melon (Fig. 4). Kim et al. (2003) also reported that short chain alcohol dehydrogenase gene was inducible by gibberellin and sucrose. In melon, expression of $8 D 10$ in CPPU-treated fruit was higher than that in pollinated fruit, which suggests that the treatment induced an increase in gibberellin and/or sucrose during early fruit development. Interestingly, short chain alcohol dehydrogenase cDNA was isolated by differential display from parthenocarpic fruit (pat) tomato ovaries (Testa et al., 2002). A possible involvement of short chain alcohol dehydrogenase in fruit set is supported by an increase in transcripts of $8 D 10$ after/during fertilization that subsequently decreased rapidly. The transcripts were readily detected in parthenocarpic fruit induced by CPPU but barely in fruit treated with 4-CPA that had little effect on parthenocarpy (Fig. 4).

The deduced amino acid sequence of 6A06 showed a similarity to histone H2A, whose cDNA was also isolated in our previous report (Nagasawa et al., 2001). We showed that histone H2A mRNA which is related to cell 
division is expressed during early stage of development in eggplant just as $6 \mathrm{~A} 06$ is related to cell division in melon.

6D05 has a similarity to an auxin binding protein, a candidate for an auxin receptor (Napier, 2001). In hot pepper (Capsicum annum), transcripts of auxin binding protein were found in the early and middle stages of fruit development (Choi, 1996). 6E04 showed a similarity to $14-3-3$ proteins that are known to interact with other proteins and regulate their activities, involving in signal transduction (Sehnke et al., 2002). In addition, 14 -3-3 protein cDNA was also isolated as a gene that is expressed during the early development of tomato fruit (Lemaire-Chamley et al., 2000). 6D05 and 6E04 may be involved in signal transduction.

The deduced amino acid sequence of $8 \mathrm{~A} 07$ has a similarity to nucleoid DNA-binding-like protein. Nucleoid DNA-binding-like protein mRNA was activated by cytokinin in tobacco (Schafer et al., 2000). Our results also showed that the expression of $8 A 07$ in CPPU - treated fruit was higher than that of 4-CPA-treated fruit (Fig. 4), suggesting that $8 A 07$ is a cytokinin inducible gene.

$8 \mathrm{C} 01$ showed a similarity to both type IIIa membrane protein and reversibly glycosylated polypeptide. The latter may play a role in plant cell wall biosynthesis as its mRNA is expressed at a high level during early cotton fiber development (Zhao and Liu, 2001). 6H01 has a similarity to an extensin-like protein whose transcripts were reported by Suyama et al. (1999) during the early stages of cucumber fruit development. Extensins are members of the family of cell wall proteins whose genes are expressed in young fruits of tomato (Salts et al. 1991). Hence, it is possible that 6H01 and $8 \mathrm{C} 01$ are related to cell wall synthesis that are required for cell enlargement.

2A10, 2C05 and 7E10 are similar to hypothetical proteins from Arabidopsis. To date, their functions are unknown, but $7 E 10$ may play important rolls in fruit set because of its specific expression in fruits (Fig. 4).

In melon, CPPU induced parthenocarpy without polli nation, whereas 4-CPA was less effective on parthenocarpy. This strengthens the speculation that $8 A 07$ (Nucleoid DNA-binding-like protein) and $8 D 10$ (Short chain alcohol dehydrogenase) may play important roles in fruit set of melon, because they are expressed at a higher level in the early stages of both pollinated and CPPU-treated fruit than in 4-CPA-treated fruit.

\section{Acknowledgements}

The authors thank Mr. K. Sakakibara for his assistance in growing the melons.

\section{Literature Cited}

Barg, R., E. Meir, D. Lapushner, R. Frankel and Y. Salts. 1990. Differential regulation of a fruit-specific $62 \mathrm{kDa}$ protein in developing parthenocarpic (pat-2/pat-2) and seeded tomato fruits. Physiol. Plant. 80: 417-424.

Callahan, A. M., P. H. Morgens and R. A. Cohen. 1993. Isolation and initial characterization of cDNAs for mRNAs regulated during peach fruit development. J. Amer. Soc. Hort. Sci. 118: 531- 537.

Carmi, N., Y. Salts, B. Dedicova, S. Shabtai and R. Barg. 2003. Induction of parthenocarpy in tomato via specific expression of the rolB gene in the ovary. Planta 217 : 726-735.

Choi, S. Y. 1996. Molecular cloning and expression of the hot pepper ERabp1 gene encoding auxin-binding protein. Plant Mol. Biol. 32: 995 - 997.

Diallinas, G., I. Pateraki, M. Sanmartin, A. Scossa, E. Stilianou, N. J. Panopoulos and A. K. Kanellis. 1997. Melon ascorbate oxidase: Cloning of a multigene family, induction during fruit development and repression by wounding. Plant Mol. Biol. 34: 759-770.

Diatchenko, L., Y. F. C. Lau, A. P. Campbell, A. Chenchik, F. Moqadam, B. Huang, S. Lukyanov, K. Lukyanov, N. Gurskaya, E. D. Sverdlov and P. D. Siebert. 1996. Suppression subtractive hybridization: A method for generating differentially regulated or tissue-specific cDNA probes and libraries. Proc. Natl. Acad. Sci. USA. 93: $6025-6030$.

Dong, Y. H., B. J. Janssen, L. R. F. Bieleski, R. G. Atkinson, B. A. M. Morris and R. C. Gardner. 1997. Isolating and characterizing genes differentially expressed early in apple fruit development. J. Amer. Soc. Hort. Sci. 122: $752-757$.

Dong, Y. H., A. Kvarnheden, J. L. Yao, P. W. Sutherland, R. G. Atkinson, B. A. Morris and R. C. Gardner. 1998. Identification of pollination-induced genes from the ovary of apple (Malus domestica). Sex. Plant Reprod. 11: $277-283$.

Esaka, M., K. Fujisawa, M. Goto and Y. Kisu. 1992. Regulation of ascorbate oxidase expression in pumpkin by auxin and copper. Plant Physiol. 100: 231-237.

Ficcadenti, N., S. Sestili, T. Pandolfini, C. Cirillo, G. L. Rotino and A. Spena. 1999. Genetic engineering of parthenocarpic fruit development in tomato. Mol. Breed. 5: 463-470.

Fos, M. and F. Nuez. 1996. Molecular expression of genes involved in parthenocarpic fruit set in tomato. Physiol. Plant. 98: 165-171.

Fos, M. and F. Nuez. 1997. Expression of genes asssociated with natural parthenocarpy in tomato ovaries. J. Plant Physiol. 151: 235-238.

Gillaspy, G., H. Ben-David and W. Gruissem. 1993. Fruits: A developmental perspective. Plant Cell 5: 1439-1451.

Hamano, M., H. Miura and Y. Tabei. 1998. Analysis of differentially expressed mRNAs during the early developmental stage of strawberry (Fragaria $\times$ ananassa Duch.) fruit by differential display technique. J. Japan. Soc. Hort. Sci. 67: 559-561.

Hayata, Y., X. X. Li and Y. Osajima. 2002. Pollination and CPPU treatment increase endogenous IAA and decrease endogenous $\mathrm{ABA}$ in muskmelons during early devel- 
opment. J. Amer. Soc. Hort. Sci. 127: 908-911.

Hayata, Y., Y. Niimi, K. Inoue and S. Kondo. 2000. CPPU and BA, with and without pollination, affect set, growth, and quality of muskmelon fruit. HortScience 35: $868-870$.

Hayata, Y., Y. Niimi and N. Iwasaki. 1995. Synthetic cytokinin 1-(2-chloro-4-pyridyl)-3-phenylurea (CPPU)-promotes fruit set and induces parthenocarpy in watermelon. J. Amer. Soc. Hort. Sci. 120: 997-1000.

Kim, J., H. G. Kang, S. H. Jun, J. Lee, J. Yim and G. An. 2003. $C \nu A D H 1$, a member of short-chain alcohol dehydrogenase family, is inducible by gibberellin and sucrose in developing watermelon seeds. Plant Cell Physiol. 44: 85-92.

Ledger, S. E. and R. C. Gardner. 1994. Cloning and characterization of five cDNAs for genes differentially expressed during fruit development of kiwifruit (Actinidia deliciosa var. deliciosa). Plant Mol. Biol. 25: 877-886.

Lee T. H., T. Kato, Y. Kanayama, H. Ohno, K. Takeno and S. Yamaki. 1997. The role of indole-3-acetic acid and acid invertase in the development of melon (Cucumis melo L. cv. Prince) fruit. J. Japan. Soc. Hort. Sci. 65: $723-729$.

Lemaire-Chamley, M., J. Petit, M. Causse, P. Raymond and C. Chevalier. 2000. Identification of differentially expressed genes during early development of tomato fruit. Characterisation of a novel cDNA coding for a RAD23 protein. Aust. J. Plant Physiol. 27: 911 - 920.

Nagasawa, M., A. Sugiyama, H. Mori, K. Shiratake and S. Yamaki. 2001. Analysis of genes preferentially expressed in early stage of pollinated and parthenocarpic fruit in eggplant. J. Plant Physiol. 158: 235-240.

Nagasawa, M., A. Sugiyama, H. Mori, K. Shiratake and S. Yamaki. 2004. Temporal expression of mRNAs after/ during fertilization in eggplant (Solanum melongena $\mathrm{L}$.) and their possible involvement in fruit set. J. Japan. Soc. Hort. Sci. 73: 221-228.

Napier, R. M. 2001. Models of auxin binding. J. Plant Growth Regul. 20: 244-254.

Reddy, A. S. N., P. K. Jena, S. K. Mukherjee and B. W. Poovaiah. 1990. Molecular cloning of cDNAs for auxin - induced mRNAs and developmental expression of the auxin-inducible genes. Plant Mol. Biol. 14: 643-653.
Rhodes, D. and A. D. Hanson. 1993. Quaternary ammonium and tertiary sulfonium compounds in higher plants. Annu. Rev. Plant Physiol. Plant Mol. Biol. 44: 357384.

Rotino, G. L., E. Perri, M. Zottini, H. Sommer and A. Spena. 1997. Genetic engineering of parthenocarpic plants. Nature Biotech. 15: 1398-1401.

Salts, Y., R. Wachs, W. Gruissem and R. Barg. 1991. Sequence coding for a novel proline-rich protein preferentially expressed in young tomato fruit. Plant Mol. Biol. 17: 149-150.

Schafer, S., S. Krolzik, G. A. Romanov and T. Schmuelling. 2000. Cytokinin-regulated transcripts in tobacco cell culture. Plant Growth Regul. 32: 307-313.

Schirch, L. 1982. Serine hydroxymethyltransferase. Adv. Enzymol. 53: 83-112.

Sehnke, P. C., J. M. DeLille and R. J. Ferl. 2002. Consummating signal transduction: The role of $14-3-3$ proteins in the completion of signal-induced transitions in protein activity. Plant Cell 14: S339-S354.

Suyama, T., K. Yamada, H. Mori, K. Takeno and S. Yamaki. 1999. Cloning cDNAs for genes preferentially expressed during fruit growth in cucumber. J. Amer. Soc. Hort. Sci. 124: 136- 139.

Testa, G., R. Caccia, F. Tilesi, G. P. Soressi and A. Mazzucato. 2002. Sequencing and characterization of tomato genes putatively involved in fruit set and early development. Sex. Plant Reprod. 14: 269- 277.

Tieman, D. M. and A. K. Handa. 1996. Molecular cloning and characterization of genes expressed during early tomato (Lycopersicon esculentum Mill.) fruit development by mRNA differential display. J. Amer. Soc. Hort. Sci. 121: 52- 56.

Yao, J. L., Y. H. Dong and B. A. M. Morris. 2001. Parthenocarpic apple fruit production conferred by transposon insertion mutations in a MADS-box transcription factor. Proc. Natl. Acad. Sci. USA. 98: 13061311.

Zhao, G. R. and J. Y. Liu. 2001. Isolation of a cotton RGP gene: a homolog of reversibly glycosylated polypeptide highly expressed during fiber development. Biochim. Biophys. Acta 1574: 370-374. 


\title{
メロンの結実過程の受精時から受精後初期に発現する遺伝子の cDNA の単離 \\ 長澤政紀・森＼cjkstart仁志・白武勝裕・山木昭平 \\ 名古屋大学大学院生命農学研究科 $464-8601$ 名古屋市千種区
}

\begin{abstract}
摘要
受精は結実のために特に重要な過程である.メロンでは 受粉後 24 時間以内には花粉管の先端は子房の基部の肧珠に 到達し，受精が完了していた：そこで，開花後1日目の受粉 した子房と無受粉の子房に由来する mRNA の間でサブトラ クションを行い, Subtracted cDNAライブラリーを作製し た. cDNAマクロアレイを用いたディファレンシャルスク リーニングとノーザン解析により，最終的に開花後 1 日目の 受粉果実のほうが無受粉果実より発現の高い14 個の cDNAクローンを得た。これらは, Ascorbate oxidase, Hydroxymethyltransferase, Phosphoethanolamine $\mathrm{N}^{-}$ methyltransferase, Short chain alcohol dehydrogenase, Histone H2A, Auxin binding protein, 14-3-3 protein, Extensin-like protein, Nucleoid DNA-binding-like

protein, Type IIIa membrane protein (Reversibly glycosylated polypeptide) および Hypothetical protein と相 同性があった．いずれも受粉果実および単為結果が引き起 こされる CPPU 処理果実で発現しており，それらの発現は 単為結果がほとんど引き起こされない4-CPA処理果実より 高かった。これらは受粉果実および CPPU 処理果実の開花 後20日目ではほとんど発現しておらず，また，そのほとん どが果実特異性の高い発現をしていた。これらの遺伝子の うち, CPPU 処理果実のほうが4-CPA 処理果実より特に 高い発現を示した $8 A 07$ (Nucleoid DNA-binding-like protein)および $8 D 10$ (Short chain alcohol dehydrogenase) がメロンの結実に特に重要な役割を果たしているのではな いかと考えられた。
\end{abstract}

